\author{
PAULINA SZYJA \\ Uniwersytet Pedagogiczny w Krakowie, Polska - Pedagogical University of Krakow, Poland \\ WoJCIECH MACIEJEWSKI \\ Uniwersytet Pedagogiczny w Krakowie, Polska - Pedagogical University of Krakow, Poland
}

\title{
Kształcenie praktyczne w uczelniach wyższych w ocenie studentów kierunku ekonomia społeczna
}

\section{Practical Education at Universities in the Opinion of Students of Social Economy}

\begin{abstract}
Streszczenie: W artykule zaprezentowano, jak studenci oceniają praktyczny wymiar kierunku ekonomia społeczna. W celu realizacji badania przedstawiono prawne aspekty opisujące praktyczny wymiar kształcenia oraz zapytano, w formie ankiety online, studentów kierunku ekonomia społeczna o opinię na temat praktycznego wymiaru studiowania. Badani odpowiadali na pytania związane z oceną programu studiów oraz ich zaangażowaniem w działania pozadydaktyczne. Poproszono ich także o rekomendacje związane z praktycznym kształceniem. Dopełnieniem badań były pytania odnoszące się do oczekiwań studentów względem wybranego kierunku, ogólnego zadowolenia ze studiów i określenia, jaki mają poziom wiedzy w porównaniu z początkiem studiów. Za największe braki w programie studiów badani uznali małą liczbę przydatnych w praktyce przedmiotów i niewystarczającą liczbę przedmiotów ekonomicznych. Duża część badanych - 38,3\% - nie była też w stanie określić, czy jej oczekiwania dotyczące kierunku studiów zostały spełnione. Zdecydowana większość badanych określiła swój stan wiedzy jako większy niż przed rozpoczęciem studiów. Wyniki badań sugerują, że należałoby upraktycznić proces kształcenia oraz zwiększyć liczbę wizyt studyjnych. Jednak studenci, poza głównie pracą zawodową, nie podejmowali indywidualnej inicjatywy w zdobywaniu praktycznego doświadczenia - tylko niewielki ich odsetek angażował się w wolontariat i działania w kołach naukowych, również niewielka liczba studentów postulowała za zwiększeniem liczby praktyk zawodowych.
\end{abstract}

\begin{abstract}
The article presents a students' assessment of the practical dimension of Social Economy as a field of study. To conduct the research, legal aspects describing the practical dimension of education were presented and social economy students were asked about the practical dimension of studying. Respondents answered questions related to the evaluation of the study programme, their involvement in undertaking non-learning activities, and they were also asked for recommendation for practical education. Complementing the research were questions related to their expectations for the chosen studies, general satisfaction and determining the feeling of their level of knowledge compared to the beginning of studies. The respondents indicated a low number of practical subjects and an insufficient number of economic subjects as the most significant shortcomings in the study program. $38.3 \%$ of respondents
\end{abstract}


were also unable to determine the satisfaction of expectations regarding the choice of Social Economy as a field of study. The vast majority described their state of knowledge to be higher than before the start of studies. Research suggests that more emphasis should be placed on practical training and increasing the number of study visits. However, apart from work, they do not undertake individual initiative in gaining practical experience as only a small percentage of them engage in volunteering and activities in scientific circle; also a tiny number postulates an increase in the number of internships.

Słowa kluczowe: ekonomia społeczna; kształcenie praktyczne; studia dualne

Keywords: dual studies; practical training; social economy

Otrzymano: 7 stycznia 2020

Received: 7 January 2020

Zaakceptowano: 30 lipca 2020

Accepted: 30 July 2020

\section{Sugerowana cytacja/Suggested citation:}

Szyja, P., Maciejewski, W. (2020). Kształcenie praktyczne w uczelniach wyższych w ocenie studentów kierunku ekonomia społeczna. Przedsiębiorczość - Edukacja [Entrepreneurship - Education], 16(2), 128-140. doi: 10.24917/20833296.162.10

\section{Wstęp}

Kształcenie praktyczne na poziomie wyższym ma być odpowiedzią na zapotrzebowanie rynku pracy na wykwalifikowanych pracowników. Absolwenci kierunków z praktycznym profilem kształcenia powinni być wyposażeni w wiedzę, umiejętności oraz postawy użyteczne na rynku pracy. Doświadczenie zdobyte przez nich w trakcie studiów ma pomóc im później w znalezieniu zawodu zgodnego ze zdobytymi kwalifikacjami oraz z własnymi zainteresowaniami i osobowymi predyspozycjami. Celem praktyk zawodowych jest nie tylko zweryfikowanie własnych umiejętności, ale także precyzyjniejsze kształtowanie ścieżki kariery zawodowej przez rzeczywisty kontakt z pracą zawodową. Program studiów powinien zatem obejmować zdobywanie wiedzy teoretycznej i praktycznej oraz rozwijać cechy osobowe i kompetencje społeczne. Należy przy tym pamiętać, że absolwent uczelni wyższej winien posiadać zaawansowaną wiedzę z obszaru, w którym się kształci. Wymusza to na autorach programów kształcenia umiejętny dobór godzin zajęć o charakterze teoretycznym i praktycznym, tak aby przekazać niezbędną wiedzę i ukształtować umiejętności jej wykorzystania.

Celem niniejszego artykułu jest analiza oczekiwań studentów dotyczących praktycznego wymiaru kształcenia i ogólna ocena ekonomii społecznej jako kierunku kształcenia. Aby ten cel osiągnąć, przeprowadzono badania ankietowe z wykorzystaniem formularzy online. Udało się uzyskać 89 poprawnie wypełnionych formularzy ankietowych. Rezultatem badań ma być lepsze poznanie oceny praktycznego kierunku kształcenia oraz dokładniejsze poznanie preferencji studentów w stosunku takiej formy kształcenia.

Artykuł składa się z czterech części. Pierwsza część stanowi wprowadzenie do tematyki kształcenia praktycznego studentów. Kolejna część uwzględnia przegląd literatury oraz wybranych badań, przeprowadzonych przez różne podmioty organizacyjne. Trzecia część stanowi wprowadzenie do metodologii badań przeprowadzonych wśród studentów kierunku ekonomia społeczna w Instytucie Prawa, Administracji i Ekonomii Społecznej Uniwersytetu Pedagogicznego w Krakowie oraz prezentuje wyniki badań. Ostatnia część 
tekstu obejmuje podsumowanie ankiety przeprowadzonej wśród studentów i jest uzupełniona o wnioski końcowe.

\section{Praktyczny wymiar kształcenia studentów - wprowadzenie do zagadnienia}

Współczesne organizacje, bez względu na ich charakter, specyfikę czy cele, podlegają dynamice zmian zarówno w odniesieniu do otoczenia zewnętrznego, jak i wewnętrznego. To powoduje konieczność dostosowywania się do nich pod względem strukturalnym, organizacyjnym, a także celów i funkcji. Organizacje publiczne nie zmieniają swoich funkcji tak szybko jak przedsiębiorstwa komercyjne. Posiłkując się przykładami uczelni wyższych i przedsiębiorstw prywatnych, można zauważyć, iż te pierwsze pełnią funkcje społeczne związane z edukacją i kształceniem, a te drugie koncentrują się przede wszystkim na zysku ze sprzedaży produktów i/lub usług o odpowiedniej jakości i cenie. Przedsiębiorstwa muszą uwzględniać kwestie zainteresowania ich produktami/usługami ze strony klientów, natomiast uczelnie dokładają starań, aby kształcić na jak najwyższym poziomie, przy czym istotne jest, czy oferowane przez nie kierunki studiów stwarzają studentom perspektywy zdobycia pracy po ukończeniu nauki. $Z$ tego względu ważne jest zatem dostosowanie treści merytorycznych, przybliżanych studentom w trakcie studiów, do oczekiwań potencjalnych pracodawców w zakresie wiedzy. Jednak na tym nie kończy się zadanie uczelni. Dziś zatrudnienie w firmach różnych branż jest uzależnione nie tylko od fachowej, nieustannie poszerzanej (np. dzięki specjalistycznym studiom podyplomowym) wiedzy, ale również od praktycznych umiejętności, które przyszli pracownicy powinni nabywać już w trakcie procesu kształcenia. Próbując sprostać owym wyzwaniom płynącym wprost z rynku, w warunkach gospodarki wolnorynkowej, poszerza się ofertę kierunków studiów o studia praktyczne lub dualne.

Podstawowe kwestie związane z kształceniem praktycznym w Polsce reguluje Ustawa $z$ dnia 20 lipca 2018 r. Prawo o szkolnictwie wyższym i nauce (Dz.U. 2018 r., poz. 1668). Jedynie uczelnie zawodowe kształcą tylko i wyłącznie na studiach o profilu praktycznym. Z kolei uczelnie akademickie mogą prowadzić „studia dualne, które są studiami o profilu praktycznym prowadzonymi z udziałem pracodawcy” (art. 62). Te ostatnie mogą również prowadzić studia o profilu praktycznym, na których „ponad połowa punktów ECTS jest przypisana zajęciom kształtującym umiejętności praktyczne” (art. 64 ust. 2 pkt 1). „Program studiów o profilu praktycznym przewiduje praktyki zawodowe w wymiarze co najmniej:

1. 6 miesięcy - w przypadku studiów pierwszego stopnia i jednolitych studiów magisterskich;

2. 3 miesięcy - w przypadku studiów drugiego stopnia” (art. 67 ust. 5 pkt 1, 2). Co więcej w ramach studiów tego rodzaju „co najmniej 50\% godzin zajęć prowadzonych jest przez nauczycieli akademickich zatrudnionych w tej uczelni jako podstawowym miejscu pracy" (art. 73 ust. 2 pkt 1).

Rozporządzenie Ministra Nauki i Szkolnictwa Wyższego z 28 września 2018 roku (Dz.U. poz. 1668) porządkuje z kolei kwestie programowe. Podkreślono w nim, że zajęcia kształtujące umiejętności praktyczne „są prowadzone:

1. w warunkach właściwych dla danego zakresu działalności zawodowej;

2. w sposób umożliwiający wykonywanie czynności praktycznych przez studentów" (art. 6 pkt 1,2). 
Powyżej przedstawiony został najbardziej aktualny zakres regulacji prezentujących kształcenie w trybie profilu praktycznego, jednak pierwsze zapisy porządkujące te kwestie zostały sformułowane w Ustawie $z$ dnia 18 marca 2011 r. o zmianie ustawy - Prawo o szkolnictwie wyższym, ustawy o stopniach naukowych i tytule naukowym oraz o stopniach i tytule $w$ zakresie sztuki oraz o zmianie niektórych innych ustaw (Dz.U. $2011 \mathrm{nr}$ 84 , poz. 455). W art. 2 ust. 1 pkt. 18e zdefiniowano, że studia o profilu praktycznym to te studia, które obejmują „moduł zajęć służących zdobywaniu przez studenta umiejętności praktycznych albo profil ogólnoakademicki, obejmujący moduł zajęć służących zdobywaniu przez studenta pogłębionych umiejętności teoretycznych”. W art. 168 nadmieniono również o możliwości prowadzenia tychże studiów z udziałem podmiotów gospodarczych. A w Rozporządzeniu Ministra Nauki i Szkolnictwa Wyższego z dnia 5 października 2011 r. w sprawie warunków prowadzenia studiów na określonym kierunku i poziomie kształcenia (Dz.U. 243, poz.1445) doprecyzowano, iż „w przypadku gdy jednostka organizacyjna uczelni prowadzi studia na danym kierunku i poziomie kształcenia na profilach ogólnoakademickim i praktycznym, zakładane efekty kształcenia opisuje się odrębnie dla każdego profilu” (art. 4 ust. 3). Odniesiono się również do kwestii kadry: „Nauczyciel akademicki może być zaliczony do minimum kadrowego określonego kierunku studiów o profilu praktycznym, jeżeli spełnia wymagania określone w ust. 1 lub posiada doświadczenie zawodowe zdobyte poza uczelnią, związane z umiejętnościami wskazanymi w opisie efektów kształcenia dla tego kierunku" (art. 12 ust. 3). We wspomnianym ustępie jest mowa o tym, że: „Nauczyciel akademicki może być zaliczony do minimum kadrowego określonego kierunku studiów o profilu ogólnoakademickim, jeżeli posiada dorobek w obszarze wiedzy, odpowiadającym obszarowi kształcenia, wskazanemu dla tego kierunku studiów, w zakresie jednej z dyscyplin naukowych lub artystycznych, do których odnoszą się efekty kształcenia dla tego kierunku” (art. 12 ust.1). Nowelizacja ustawy z 2016 r. rozszerzyła definicję profilu praktycznego (Dz.U. 2016 poz. 1842): „profil programu kształcenia obejmującego moduły zajęć służące zdobywaniu przez studenta umiejętności praktycznych i kompetencji społecznych, realizowany przy założeniu, że ponad połowa programu studiów określonego w punktach ECTS obejmuje zajęcia praktyczne kształtujące te umiejętności i kompetencje, w tym umiejętności uzyskiwane na zajęciach warsztatowych, które są prowadzone przez osoby posiadające doświadczenie zawodowe zdobyte poza uczelnią" (art. 2 ust. 1 pkt. 18 ea). Doprecyzowano również kwestie obsady, m.in.:

„2.30) Podstawowa jednostka organizacyjna uczelni prowadząca studia pierwszego lub drugiego stopnia lub jednolite studia magisterskie o profilu praktycznym może zaliczyć do minimum kadrowego, w miejsce nauczyciela akademickiego posiadającego tytuł naukowy profesora lub stopień naukowy doktora habilitowanego lub będącego osobą, która nabyła uprawnienie równoważne z uprawnieniami doktora habilitowanego na podstawie art. 21a ustawy z dnia 14 marca 2003 r. o stopniach naukowych i tytule naukowym oraz o stopniach i tytule $\mathrm{w}$ zakresie sztuki, dwie osoby posiadające stopień naukowy doktora i znaczne doświadczenie zawodowe zdobyte poza uczelnią w dziedzinie związanej z kierunkiem studiów.

3. Podstawowa jednostka organizacyjna uczelni, o której mowa w ust. 2, może zaliczyć do minimum kadrowego, w miejsce nauczyciela akademickiego posiadającego stopień naukowy doktora, dwie osoby posiadające tytuł zawodowy magistra i znaczne doświadczenie zawodowe zdobyte poza uczelnią w dziedzinie związanej z kierunkiem studiów. 
4. ${ }^{31)}$ Liczba osób, o których mowa w ust. 2 lub 3, nie może przekroczyć 50\% liczby osób zaliczanych do minimum kadrowego" (art. 9a).

Za cele przyświecające realizacji kształcenia na kierunkach studiów o profilu praktycznym należy uznać:

- powiązania nauczania akademickiego z potrzebami gospodarki,

- poprawę relacji pomiędzy ośrodkami akademickimi a przedsiębiorstwami,

- zaznajomienie studentów ze specyfiką pracy w przedsiębiorstwach,

- stworzenie warunków dla zatrudnienia studentów po ukończeniu przez nich studiów w przedsiębiorstwach, w których odbywali praktyki studenckie.

Część z tych celów została zarysowana pośrednio w uzasadnieniu dla projektu nowelizacji ustawy przyjętej w 2011, gdzie wskazano m.in. na następującą bolączkę polskiego szkolnictwa wyższego: „słabe powiązanie uczelni z otoczeniem społeczno-gospodarczym - nadal zbyt słaba jest współpraca uczelni ze środowiskiem pracodawców z sektora publicznego, komercyjnego oraz pozarządowego. Oferta dydaktyczna większości polskich uczelni ma charakter podażowy, jest nieelastyczna oraz rzadko podlega zewnętrznej ewaluacji pod względem efektów kształcenia” (uzasadnienie 3391).

Zmiany w ustawie spotkały się ze zróżnicowanymi opiniami środowiska akademickiego. To, co jednak przeważało w opiniach, to kwestia sposobu organizacji praktyk i odpowiedzialności uczelni w tym zakresie. W art. 11 b ust. 9 wskazano: „Podstawowa jednostka organizacyjna uczelni prowadząca kształcenie na określonym kierunku studiów i poziomie kształcenia o profilu praktycznym jest obowiązana uwzględnić w programie kształcenia co najmniej trzymiesięczne praktyki zawodowe. Jednostka ta może organizować kształcenie przemiennie w formie zajęć dydaktycznych realizowanych w uczelni i w formie praktyk odbywanych u pracodawcy, uwzględniając realizację wszystkich efektów kształcenia przewidzianych w programie kształcenia dla tego kierunku, poziomu i profilu kształcenia”. Kolejna odsłona ustawy, jak wspomniano powyżej, zdecydowanie doprecyzowała zakres czasowy tego obowiązku. Te kwestie stanowią podstawę dalszych rozważań w niniejszym opracowaniu.

\section{Założenia programowe dla praktycznych kierunków kształcenia}

Zapewnienie studentom praktyk nie jest rzeczą łatwą. Wynika to z szeregu barier, czy też ograniczeń o charakterze zarówno organizacyjnym, administracyjnym, technicznym, finansowym, jak i mentalnym. Z raportu, przygotowanego na podstawie wyników projektu „Laboratorium Kariery”, którego jednym z elementów były badania opinii studentów na temat zrealizowanych praktyk zawodowych, wynika, że:

- studenci podejmowali praktyki zawodowe z uwagi na chęć zyskania doświadczenia zawodowego,

- wybór praktyki uzależniali od dogodnych warunków odbycia praktyki,

- największym zainteresowaniem cieszyły się prace organizowane przez małe i średnie przedsiębiorstwa,

- wybór konkretnej firmy na miejsce odbycia praktyk był uzależniony od spełnienia wymogów stawianych przez przedsiębiorców,

- studenci uznali, że największymi atutami na rynku pracy są determinacja i wiedza. Z kolei przedsiębiorcy, z którymi przeprowadzono wywiady, zwrócili uwagę m.in. na to, iż: 
- studenci powinni wykazywać się większą inicjatywą, ubiegając się o praktyki,

- uczelnie powinny ściślej współpracować z rynkiem pracy (Fundacja Pracownia Jutr, 2015: 6-15).

W jednym z opracowań, opublikowanym w 2015 r., wskazano na bariery współpracy przedsiębiorców z uczelniami i na odwrót. Zdaniem przedsiębiorców główne problemy dotyczyły m.in. nadmiernej biurokracji towarzyszącej nawiązaniu współpracy, odmiennych oczekiwań firm i uczelni dotyczących współpracy, niedostosowania programów edukacyjnych do potrzeb pracodawców. Z kolei uczelnie podkreślały niewystarczający poziom finansowania praktyk przez przedsiębiorstwa, nadmierną biurokrację, brak zainteresowania ze strony przedsiębiorców, odmienne cele i wartości partnerów (Hermann-Pawłowska i in., 2015: 9-11). W efekcie przeprowadzonych badań „nie znaleziono dowodów na to, by jakość odbywanych praktyk i staży istotnie przekładała się na szansę późniejszego zatrudnienia" (Hermann-Pawłowska i in., 2015: 80).

Aby sprostać tym wyzwaniom, zdaniem autorów niniejszego artykułu konieczne są m.in. odpowiednie założenia programowe dla praktycznych kierunków kształcenia. W kontekście przeprowadzonych badań ankietowych studentów kierunku ekonomia społeczna warto odwołać się do efektów kształcenia. Podkreślono w nich: „Praktyczny profil studiów oraz zbilansowany plan studiów, obejmujący kursy teoretyczne i praktyczne pozwolą na zdobycie szerokiej i aktualnej wiedzy ekonomicznej oraz przydatnych praktycznych umiejętności. Wiedza, umiejętności i kompetencje uzyskane przez absolwentów kierunku ekonomia społeczna w efekcie dają szerokie przygotowanie do pracy w jednostkach administracji rządowej i samorządowej, w sektorze pożytku publicznego, w różnorodnych instytucjach społecznych i organizacjach non profit" (Wydział Politologii, 2019).

\section{Badania oceny praktycznego kształcenia dokonanej przez studentów kierunku ekonomia społeczna}

Kierunek ekonomia społeczna istnieje na Uniwersytecie Pedagogicznym w Krakowie od roku akademickiego 2016/2017. Ideą tego kierunku jest przygotowanie kadr dla szeroko rozumianego trzeciego sektora, ze szczególnym uwzględnieniem podmiotów ekonomii społecznej. Kursy zawarte w programie kształcenia uwzględniają praktyczny wymiar kształcenia, zapewniają odpowiednią liczbę praktyk zawodowych oraz dużą liczbę zajęć w formie ćwiczeń i warsztatów.

Diagnoza oceny praktycznego wymiaru kształcenia na tym kierunku dokonywanej przez studentów pozwoliła w większym stopniu dowiedzieć się, jak istniejący program kształcenia odpowiada ich potrzebom. Autorzy artykułu są świadomi, że ocena badanych może być oceną nie tylko praktycznego wymiaru studiów, ale też ogólnego postrzegania procesu kształcenia. Uznali oni też, że wiedza na temat oczekiwań ze strony studentów ma swoją wartość poznawczą i może być rozszerzeniem wiedzy badań nad edukacją.

Do badań opracowano ankietę w formie internetowej, składającą się z 17 pytań, w tym 2 pytań stanowiących metryczkę. Pytania zwarte w ankiecie nie dotyczyły jedynie oceny praktycznego wymiaru kształcenia, ale także oceny innych aspektów związanych z kształceniem. Badaną populację stanowiło 153 studentów kierunku ekonomia społeczna ${ }^{1}$.

\footnotetext{
${ }^{1}$ Stan na dzień 1 czerwca 2019 r.
} 
W badaniach uzyskano 89 poprawnie uzupełnionych formularzy, co stanowiło $58,2 \%$ populacji. Najliczniej reprezentowani byli studenci pierwszego roku studiów I stopnia ich udział wyniósł 83,7\% subpopulacji. Najmniej liczną grupę stanowili studenci drugiego roku studiów II stopnia, od których uzyskano tylko dwa formularze, co odpowiadało $13,3 \%$ tej subpopulacji. W pozostałych przypadkach udział studentów w ich subpopulacjach stanowił blisko 50\%, z odchyleniem maksymalnie $4,1 \%$.

Tabela 1. Liczebność subpopulacji badanych wg roku i stopnia studiów

\begin{tabular}{|l|c|c|c|c|c|c|}
\cline { 2 - 7 } \multicolumn{1}{c|}{} & $\mathbf{1}$ lic. & $\mathbf{2 ~ l i c . ~}$ & $\mathbf{3 ~ l i c .}$ & $\mathbf{1 ~ \mathbf { ~ m g r }}$ & $\mathbf{2 ~ \mathbf { ~ m g }}$ & Suma \\
\hline $\begin{array}{l}\text { Badana } \\
\text { populacja }\end{array}$ & 41 & 12 & 21 & 13 & 2 & 89 \\
\hline Populacja & 49 & 24 & 37 & 28 & 15 & 153 \\
\hline $\begin{array}{l}\text { Udział badanych } \\
\text { w subpopulacji }\end{array}$ & $83,7 \%$ & $50,0 \%$ & $54,1 \%$ & $46,4 \%$ & $13,3 \%$ & $58,2 \%$ \\
\hline
\end{tabular}

1 lic. - liczba studentów na pierwszym roku studiów I stopnia

2 lic. - liczba studentów na drugim roku studiów I stopnia

3 lic. - liczba studentów na trzecim roku studiów I stopnia

$1 \mathrm{mgr}$ - liczba studentów na pierwszym roku studiów II stopnia

2 mgr - liczba studentów na drugim roku studiów II stopnia

Źródło: badania własne $\mathrm{N}=89$

Z uwagi na wielkość badanej populacji i liczbę zgromadzonych formularzy wyniki badań są reprezentatywne przy $a=0,95$, wielkości frakcji 0,5 i błędzie maksymalnym na poziomie 0,0677 . Ze względu na powyższe rezultaty badań posiadają one zbyt wysoki błąd maksymalny, aby można było je generalizować dla całej populacji.

Jednym z ważniejszych motywów decyzji o podjęciu studiów wyższych są plany i oczekiwaniami związane z karierą zawodową (Jarecki, 2015; Maciejewski, Faron, 2019). Z tego, a także z pozostałych powodów, przed wyborem kierunku kształcenia kandydaci mają określone oczekiwania dotyczące wiedzy, którą nabędą w trakcie studiów. Dane zamieszczone na rycinie 1 wskazują, że niemal połowa, 48,3\%, badanych studentów kierunku ekonomia społeczna oczekiwała dużej liczby przedmiotów ekonomicznych w programie kształcenia, zdecydowanie mniejsza grupa, bo 29,2\% badanych, zrównoważonej liczby przedmiotów z zarządzania, ekonomii i w sektorze non profit.

Pozostałe odpowiedzi związane z oczekiwaniami dotyczącymi wybranego kierunku studiów mogą nieco zaskakiwać, ponieważ zarządzanie przedsiębiorstwem i problemy społeczne, mimo że częściowo powiązane, są przedmiotem innych kierunków studiów.

Wybór praktycznego kierunku studiów, którym jest ekonomia społeczna, powinien zaspokoić potrzeby studenta w zakresie pozyskiwania wiedzy praktycznej. Zgodnie z danymi zamieszczonymi na rycinie 2 , w ocenie $30,3 \%$ badanych w programie studiów przewidziana była niewystarczająca liczba przedmiotów przydatnych w praktyce. Niewiele mniej respondentów - 28,1\% - wskazało, że brakuje przedmiotów ekonomicznych, co jest zgodne z oczekiwaniami badanych. Studenci wskazywali też na niedosyt ciekawie prowadzonych zajęć - taką odpowiedź wskazało 18\% ankietowanych.

Niewielka liczba zajęć z praktykami to według 11,2\% studentów niedomiar programu studiów, mimo że z obserwacji autorów wynika, że Uniwersytet Pedagogiczny w Krakowie oferuje dużą liczbę zajęć dodatkowych, m.in. zajęcia z praktykami biznesu. 
Rycina 1. Oczekiwania badanych względem kierunku ekonomia społeczna

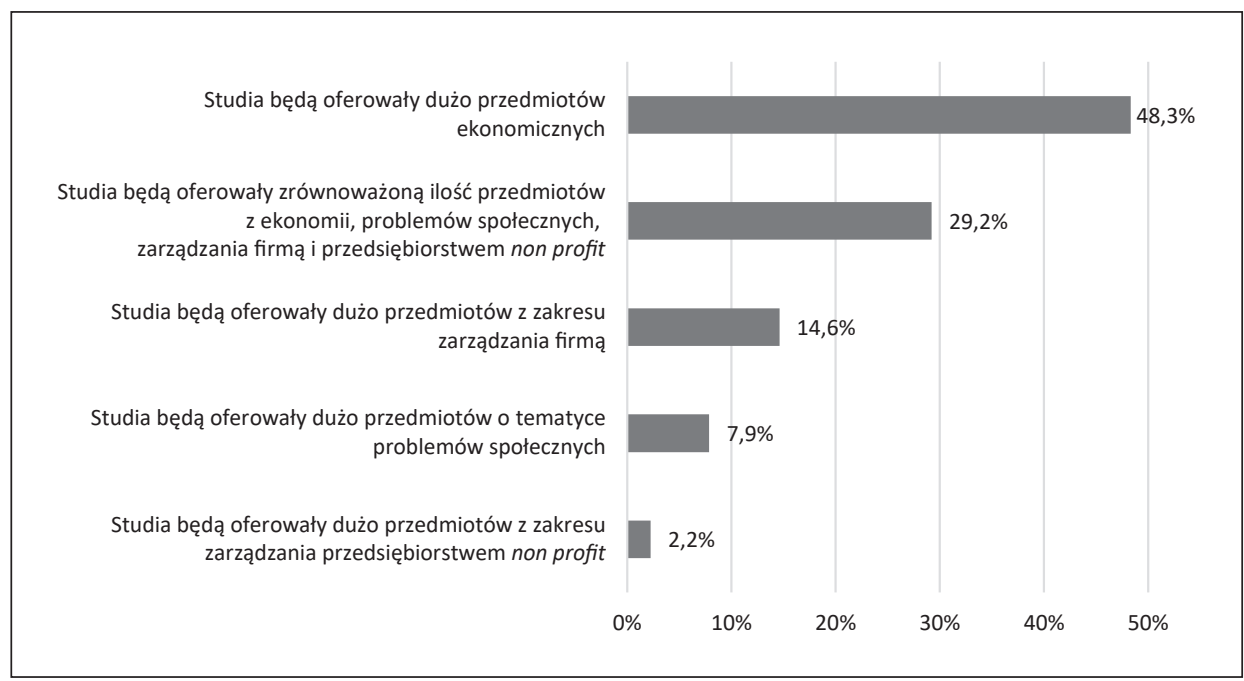

Źródło: badania własne, $\mathrm{N}=89$

Rycina 2. Ocena, których elementów najbardziej brakuje w programie studiów

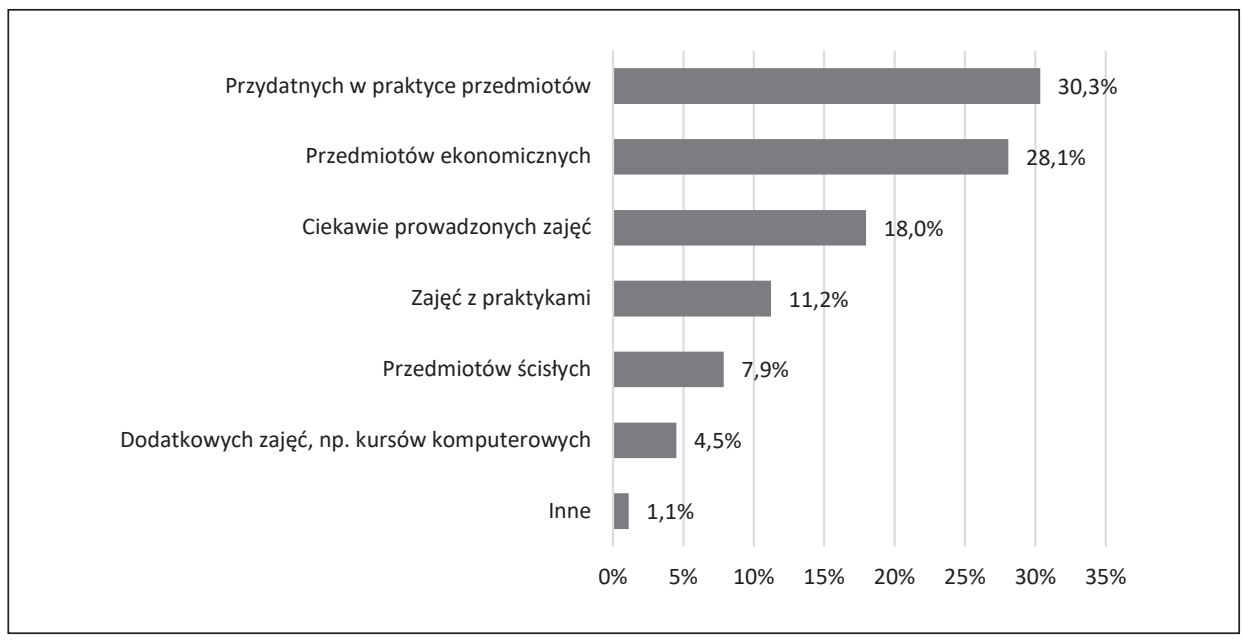

Źródło: badania własne, $\mathrm{N}=89$

W odniesieniu do wcześniejszych odpowiedzi badanych zamieszczone na rycinie 3 dane nie wydają się być zaskakujące, szczególnie w przypadku trzech najczęściej powtarzających się odpowiedzi. Studenci oczekiwali większej liczby praktycznych przedmiotów i wizyt studyjnych oraz lepiej ułożonego harmonogramu. Są to dość często postulowane, w rozmowach studentów, propozycje zmian ${ }^{2}$. Co ciekawe, 10,1\% respondentów proponowało, aby w programie studiów było mniej praktyk. Mimo że nie jest to wysoka wartość

${ }^{2}$ Autorzy zadawali pytania studentom kierunku ekonomia społeczna o ich opinie dotyczące procesu studiowania. 
Rycina 3. Propozycje zmian w programie studiów w ocenie badanych

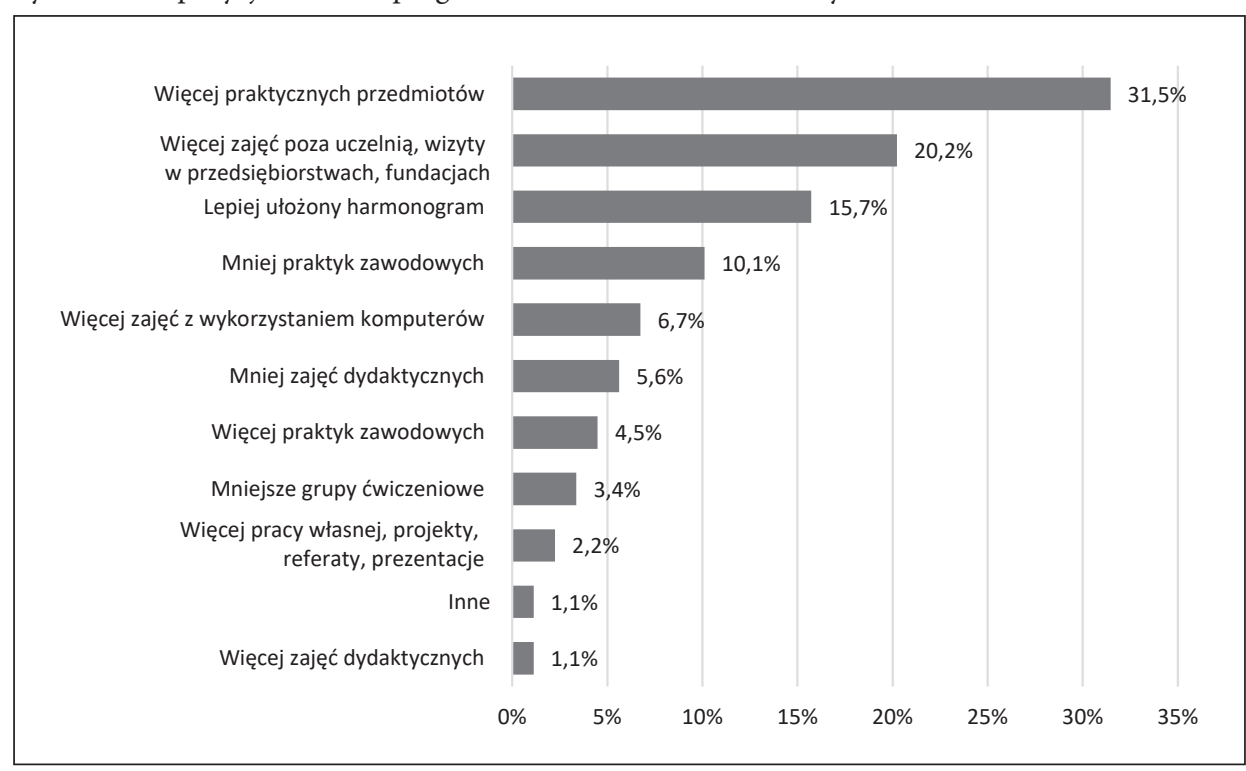

Źródło: badania własne, $\mathrm{N}=89$

wskazań, to może dziwić na tle pozostałych propozycji. Jednocześnie zaledwie 4,5\% studentów postulowało zwiększenie liczby praktyk zawodowych.

Wręcz marginalna liczba wskazań dotyczyła propozycji zwiększenia liczby zajęć dydaktycznych (1,1\%), większej pracy własnej studenta (2,2\%), czy zmniejszenia liczebności grup ćwiczeniowych $(3,4 \%)$.

Studenci biorący udział w badaniu postulowali zwiększenie praktycznego wymiaru studiów przez zwiększenie liczby zajęć praktycznych i wizyt studyjnych. Trudno odmówić słuszności takim postulatom, gdyż takie zajęcia i wizyty z pewnością uatrakcyjniają ofertę kierunku studiów i mogą zwiększyć zaangażowanie studenta w proces nauczania. Dydaktyczne doświadczenia autorów wskazują na to, że nie zawsze deklarowanie chęci praktyczniejszego podejścia do nauki idą w parze $\mathrm{z}$ rzeczywistym zainteresowaniem ze strony studentów, szczególnie gdy wymaga się od studentów poświęcenia dodatkowego czasu, poza zajęciami przewidzianymi w harmonogramie studiów.

Na rycinie 4 zamieszczono dane dotyczące zaangażowania studentów w aktywności wykraczające poza program studiów. Największa aktywność studentów związana jest z podejmowaniem pracy zawodowej - $42,7 \%$ badanych uznało to za pozadydaktyczną formę zdobywania wiedzy i umiejętności. Z pewnością pracę zawodową należy uznać za praktyczną formę pozyskiwania doświadczenia. Niestety, na podstawie przeprowadzonych badań nie można stwierdzić, czy podejmowana praca była wynikiem chęci zdobycia doświadczenia, czy koniecznością wynikającą z sytuacji finansowej.

Uczestnictwo w konferencjach naukowych to także popularna forma angażowania się w zajęcia pozadydaktyczne, taką odpowiedź zaznaczyło 33,7\% badanych. Autorzy badań mają jednak wątpliwość, czy mimo wyraźnego opisaniu kafeterii wyboru studenci rozróżnili bierny i aktywny udział w konferencji. Związek kierunku z trzecim sektorem nie przekładał się też na zaangażowanie w wolontariat - niewielu badanych (9\%) zaznaczyło 
Rycina 4. Zaangażowanie studentów ekonomii społecznej w zajęcia pozadydaktyczne

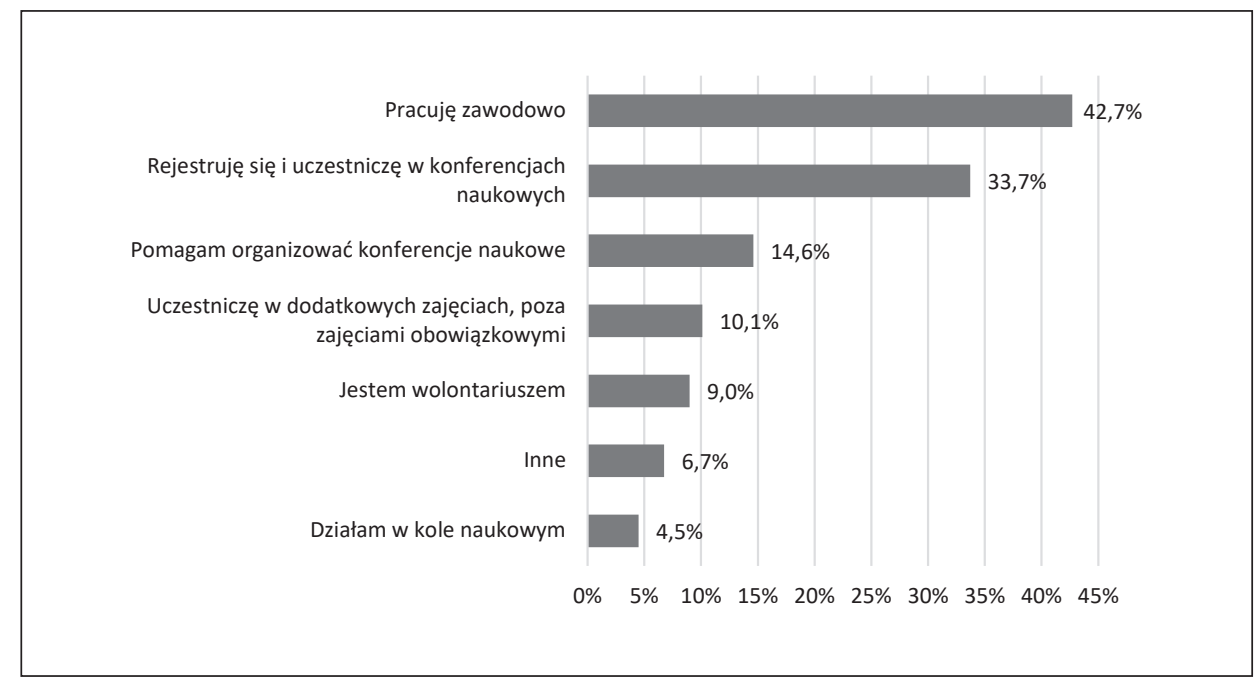

Źródło: badania własne, $\mathrm{N}=89$

taką formę aktywności. Trudno poddać ocenie tak niewielką popularność wolontariatu. Być może jest to efekt braku wolnego czasu ze względu na pracę zawodową. Najmniej popularną formą udziału w pozadydaktycznych zajęciach była działalność w kołach naukowych. Marginalna część badanych, 4,5\% studentów, zadeklarowała przynależność do takich kół. Wśród odpowiedzi „inne”, najczęściej pojawiały się określenia „W ogóle się nie angażuję".

Przeglądając powyższe opinie badanych, można dojść do wniosku, że program studiów ma wyraźne braki, zwłaszcza w zakresie praktycznego kształcenia. Jeszcze mniej optymistycznie prezentują się dane z ryciny 5, ponieważ wynika z nich, że aż $25,8 \%$ studentów stwierdziło, iż wybrane studia nie spełniają ich oczekiwań, a aż 13,5\% zdecydowanie nie jest zadowolonych z dokonanego wyboru.

Największa część studentów (39,3\%) nie potrafiła określić, czy jej oczekiwania w stosunku do kierunku studiów zostały spełnione. Natomiast 16,9\% studentów uznało, że ich oczekiwania zostały zaspokojone, a tylko 4,5\% uznało, że oczekiwania zostały zdecydowanie spełnione. Dane z ryciny 5 z jednej strony można uznać za niepokojące, gdyż więcej jest studentów, którzy odczuwają brak spełnienia oczekiwań, ale z drugiej strony należy wziąć pod uwagę, że ocena dokonywana w trakcie procesu studiowania może nie dawać obiektywnego wyniku.

Studia wyższe to przede wszystkim zdobywanie wiedzy i umiejętności, które wiążą się zarówno z nauką teorii, jak i praktycznego jej wykorzystania.

Studenci kierunku ekonomia społeczna w zdecydowanej większości $(69,2 \%)$ określili, że ich stan wiedzy zwiększył się od momentu rozpoczęcia studiów. Niewielka część respondentów określiła, że wie mniej (1,1\%), a także, że wie zdecydowanie mniej (3,3\%). Ten wynik może wynikać z faktu, że zdobywaniu wiedzy czasem towarzyszy wrażenie, że posiadamy jej mniejszy zasób niż początkowo się nam wydawało. Stosunkowo spora grupa badanych $(18,7 \%)$ określiła, że posiada tyle samo wiedzy co przed rozpoczęciem studiów. 
Rycina 5. Spełnienie oczekiwań badanych z wyboru kierunku kształcenia

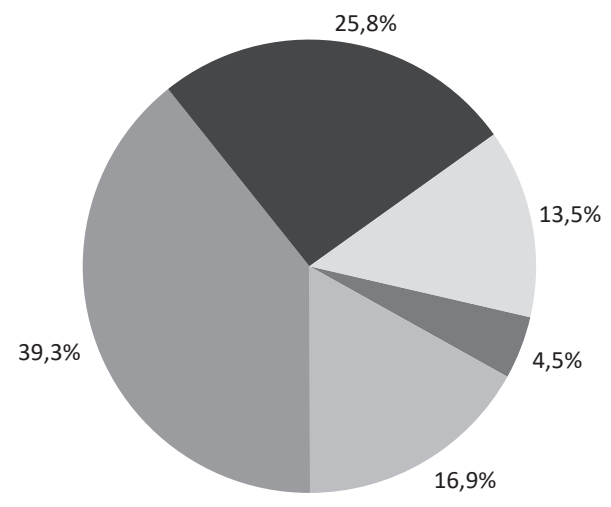

Zdecydowanie tak $\quad$ Tak $\square$ Ani tak, ani nie $\square$ Nie Zdecydowanie nie

Źródło: badania własne, $\mathrm{N}=89$

Rycina 6. Określenie posiadanej wiedzy po rozpoczęciu studiów

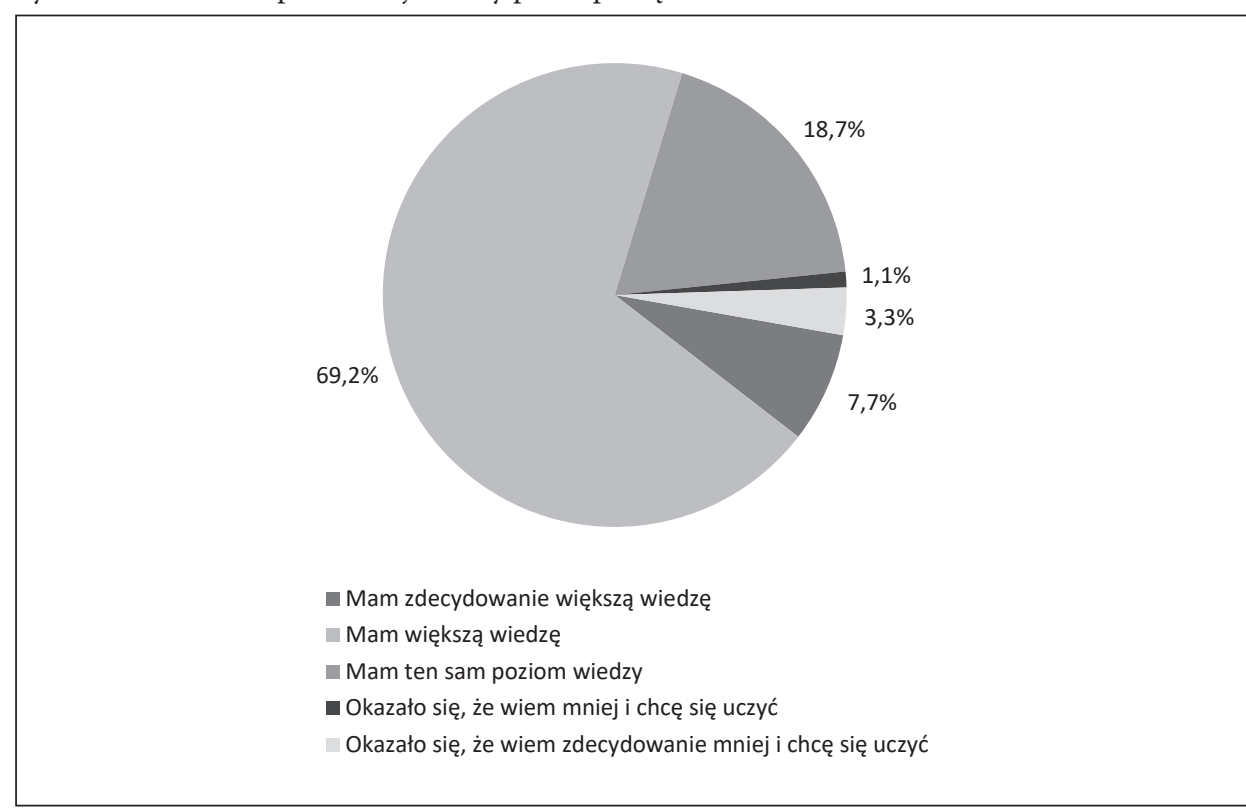

Źródło: badania własne, $\mathrm{N}=89$

\section{Dyskusja i podsumowanie wyników badań}

Studia w wymiarze praktycznym dają możliwość uzyskania wiedzy i umiejętności, które można wykorzystać w przestrzeni społeczno-gospodarczej. Wymaga to jednak 
odpowiedniego programu studiów, przewidującego możliwość zdobycia zarówno wiedzy teoretycznej, jak i praktycznej. Według raportu Deloitte (Deloitte, 2018), najlepszymi i najużyteczniejszymi źródłami doświadczenia zawodowego są praca i praktyki związane z kierunkiem studiów oraz wolontariat. W ocenach studentów prezentowanych w niniejszym artykule powyższe źródła zdobywania doświadczenia nie zajmują wysokiego miejsca - zaledwie 9\% badanych angażowało się w wolontariat, a 4,5\% uważało, że w programie studiów powinno być więcej praktyk zawodowych. Studenci zgłaszali głównie postulaty dotyczące zwiększenia wymiaru praktycznych przedmiotów, a także większej liczby wizyt studyjnych. Trudno wyprowadzić wniosek dotyczący oceny przez badanych praktycznego wymiaru kształcenia, gdyż z jednej strony zwracali oni uwagę na małą liczbę zajęć praktycznych, a z drugiej strony - poza pracą zawodową i udziałem w konferencjach nie podejmowali inicjatyw wymagających indywidualnego zaangażowania w podnoszenie swoich kompetencji.

Praktyczne kształcenie nie oznacza uzyskania gotowych rozwiązań na wyzwania pojawiające się w życiu zawodowym. Program studiów praktycznych ma pomóc studentowi w zdobyciu umiejętności i wiedzy, a także odpowiednich do kierunku kształcenia kompetencji społecznych. Samo praktyczne kształcenie bez wprowadzenia teoretycznego nie umożliwi studentom poznania zasad funkcjonowania rzeczywistości społeczno-gospodarczej. Kształcenie teoretyczne przekazuje uporządkowaną wiedzę na temat otaczającej nas rzeczywistości, same praktyczne umiejętności pozwalają jedynie na odtwórcze działanie, nie są wystarczające do wprowadzania twórczych rozwiązań.

Pomimo niewystarczającej liczby zajęć praktycznych i sporej liczby osób z niespełnionymi oczekiwaniami dotyczącymi wyboru studiów, zdecydowana większość studentów deklarowała posiadanie większej wiedzy dzięki studiom.

Uzupełnieniem badań, dającym bardziej obiektywny poogląda na temat praktycznego wymiaru kształcenia, mogłaby okazać się analiza losów zawodowych absolwentów kierunku ekonomia społeczna.

Literatura

References

Deloitte. (2018). First Steps into the Labour Market, International survey of students and graduates. Central Europe 2018. Pozyskano z: https://www2.deloitte.com/content/dam/Deloitte/ce/ Documents/about-deloitte/ce-first-steps-into-the-labour-market-2018.pdf

Fundacja Pracownia Jutr. (2015). Raport podsumowujący oczekiwania studentów i pracodawców w związku $z$ organizacją praktyk i staży studenckich. Laboratorium Kariery. Rybik.

Hermann-Pawłowska, K., Leszczyńska, B., Trzciński, R., Sondej, K. (2015). Badanie ewaluacyjne o charakterze on-going identyfikujące dobre praktyki $w$ realizacji praktycznych elementów kształcenia $w$ projektach dofinansowanych $w$ ramach IV Priorytetu PO KL oraz $w$ innych działaniach $w$ obszarze szkolnictwa wyższego. Raport końcowy. DANAE, IDEA. Pozyskano z: https://www.ncbr.gov.pl/fileadmin/user_upload/import/tt_content/files/praktyczne_elementy_ksztalcenia_-_ewaluacja.pdf

Jarecki, W. (2015). Motywacje przy podejmowaniu studiów wyższych ekonomicznych. Annales. Etyka w Życiu Gospodarczym, 17(3), 133-141.

Maciejewski, W., Faron, A. (2019). Factor of choosing the tourism and recreation field of study in the context of the tourism sector development. W: M. Dolezalova, J. Mallinu, P. Scholz (red.), Topical Issues of Tourism, Tural Tourism - possibility for a destination. Jihlava: Published by College of Polytechnics Jihlava, 175-185. 
Obwieszczenie Marszałka Sejmu Rzeczypospolitej Polskiej z dnia 26 października 2016 r. w sprawie ogłoszenia jednolitego tekstu ustawy - Prawo o szkolnictwie wyższym. Dz.U. 2016, poz. 1842.

Rozporządzenie Ministra Nauki i Szkolnictwa Wyższego z dnia 27 września 2018 r. w sprawie studiów. Dz.U. poz. 1668.

Rozporządzenie Ministra Nauki i Szkolnictwa Wyższego z dnia 5 października 2011 r. w sprawie warunków prowadzenia studiów na określonym kierunku i poziomie kształcenia. Dz.U. 243, poz. 1445.

Ustawa z dnia 31 stycznia 2019 r. o zmianie ustawy - Prawo o szkolnictwie wyższym i nauce. Dz.U. 2019 r., poz. 276.

Ustawa z 20 lipca 2018 r. Prawo o szkolnictwie wyższym i nauce. Dz.U. 2018 r., poz. 1668.

Ustawa z dnia 18 marca 2011 r. o zmianie ustawy - Prawo o szkolnictwie wyższym, ustawy o stopniach naukowych i tytule naukowym oraz o stopniach i tytule $w$ zakresie sztuki oraz o zmianie niektórych innych ustaw. Dz.U. $2011 \mathrm{nr}$ 84, poz. 455

Wydział Politologii. (2019, 29 października). Efekty kształcenia dla prowadzonych na Wydziale Politologii kierunków studiów. Pozyskano z: https://wpl.up.krakow.pl/student-2-2/efekty-ksztalcenia/

Wojciech Maciejewski, dr, adiunkt w Katedrze Ekonomii i Polityki Gospodarczej Uniwersytetu Pedagogicznego im. Komisji Edukacji Narodowej w Krakowie. Członek zarządu Stowarzyszenia Naooka. Jego zainteresowania badawcze dotyczą obszarów przedsiębiorczości, cech przedsiębiorczych, problematyki decyzji oraz czynników wpływających na powodzenie przedsięwzięć gospodarczych.

Wojciech Maciejewski, PhD, assistant professor in the Department of Economics and Economic Policy of the Pedagogical University of Krakow. Member of the board of the Naooka Association. His research interests concern the areas of entrepreneurship, entrepreneurial features, decision issues and factors affecting the success of business ventures.

ORCID: https://orcid.org/0000-0002-5761-0489

\section{Adres/Address:}

Uniwersytet Pedagogiczny im. Komisji Edukacji Narodowej

Instytut Prawa Administracji i Ekonomii

ul. Podchorążych 2

30-084 Kraków, Poland

e-mail: wmaciejewski@up.krakow.pl

Paulina Szyja, dr, adiunkt w Katedrze Badań nad Zrównoważonym Rozwojem Uniwersytetu Pedagogicznego im. Komisji Edukacji Narodowej w Krakowie.

Paulina Szyja, PhD, assistant professor in the Department of Economics and Economic Policy of the Pedagogical University of Krakow.

ORCID: https://orcid.org/ 000-0002-9672-1341

\section{Adres/Address:}

Uniwersytet Pedagogiczny im. Komisji Edukacji Narodowej

Instytut Prawa Administracji i Ekonomii

ul. Podchorążych 2

30-084 Kraków, Poland

e-mail: paulina.szyja@up.krakow.pl 